\title{
Aniline Derived Bis-Schiff Base - Analytical Reagent for the Assay of Fe (III)
}

\begin{abstract}
GLADIOLA TANTARU, NELA BIBIRE, ALINA DIANA PANAINTE, MADALINA VIERIU*, MIHAI APOSTU
Grigore T. Popa University of Medicine and Pharmacy of lasi, Faculty of Pharmacy, 16th Universitatii St., 700115, Iasi, Romania

A new spectrophotometric method for the quantitative determination of Fe (III) was established based on the complexation reaction with a new bis-Schiff base, 4,4'-methylenebis-salicylidene aniline, when a stable complex with an absorption maximum at $520 \mathrm{~nm}$ was obtained. The conditions of the complexation reaction were established and the method was validated according to ICH guidelines in terms of linearity, accuracy, precision of the method and the limits of detection and quantification were determined. The method was applied with good results for the quantitative determination of Fe (III) in pharmaceutical products.
\end{abstract}

Keywords: spectrophotometry, bis-Schiff base, complexation, iron (III).

The biological role of metallic ions [1] and that of their ligands in some physiological and pathological processes within the biological systems can be explained through the formation of complexes [2]. Among the mostimportant in vitro or in vivo biological ligands, there are aminoacids, Schiff bases and bis-Schiff bases, peptides, nucleotides, nucleic acids, proteins porphyrins and other multidentate organic bases [3-15].

$\mathrm{Fe}$ (III) can be quantitatively determined directly using a new spectrophotometric method. The optimum conditions for the complexation reaction using a type ONNO bis-Schiff base (fig. 1) have been determined by studying the following parameters: reaction $\mathrm{pH}$, formation time, stability in time of the complex, cation/ligand combination ratio, conditional stability constant $(\beta n)$ [16-19].

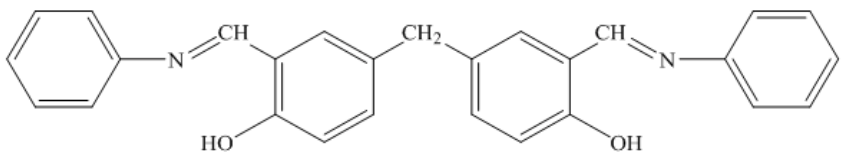

Fig. 1. Chemical structure of 4,4'-methylene bis-salicyliden aniline

\section{Experimental part}

$\mathrm{Fe}(\mathrm{III})$ ions formed a complex combination with 4,4'methylen bis-salicylidene aniline (BSB) at $p \mathrm{H}=4.5$ and its absorbance measured at $520 \mathrm{~nm}$ was proportional to the concentration of the ions. The optimum wavelength for detection and the optimum working conditions were established. In order to evaluate the performance parameters of the method (linearity, precision and accuracy) solutions in the $5-30 \mu \mathrm{g} / \mathrm{mL} \mathrm{Fe}(\mathrm{III})$ concentration range have been used.
When establishing the optimum wavelength for the detection, $1 \mathrm{~mL}$ of $5-30 \mu \mathrm{g} / \mathrm{mL}$ Fe(III) solution was brought to $\mathrm{pH} 4.5$ using acetate buffer, and $2 \mathrm{~mL}$ acetone and $1 \mathrm{~mL}$ BSB $1 \%(w / v)$ solution in methanol were added. After 10 min, the absorbance of the light-red complex was measured at $520 \mathrm{~nm}$ against the blank sample.

\section{Method validation}

In order to determine the linearity of the method 5-30 $\mu \mathrm{g} / \mathrm{mL}$ Fe (III) solutions have been used. The obtained data was analyzed by linear regression and the calibration curve was obtained [20-22]. Detection and quantification limits were calculated using the following formulas [21]: LOD = 3.Standard error/slope and LOQ = 10.Standard error/slope. In order to determine the precision of the method [2124], three solutions containing 15,20 and $25 \mu \mathrm{g} / \mathrm{mL} \mathrm{Fe}(I I I)$ ions were used. Three assays were performed for each concentration level. The assay was performed twice in two different days in order to evaluate the intermediary precision.

In order to establish the accuracy of the method three $\mathrm{Fe}(\mathrm{III})$ solutions were used for three concentration levels: 15,20 and $25 \mu \mathrm{g} / \mathrm{mL}$. For each solution, three determinations were performed [21, 23-27].

\section{Results and discussions}

The absorption spectrum of the complex (fig. 2) showed a maximum of absorbance at $520 \mathrm{~nm}$.

The influence of $\mathrm{pH}$ on the complexation reaction was studied and the optimum $\mathrm{pH}$ value was established at $\mathrm{pH}$ 4.5 (fig. 3).

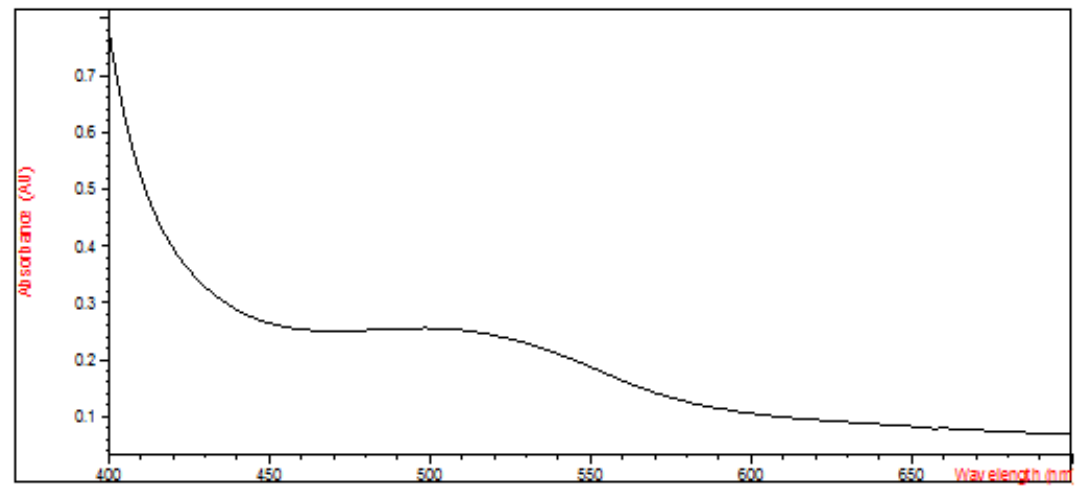

Fig. 2. Absorption spectrum of the complex

* email: madalina.vieriu@umfiasi.ro 


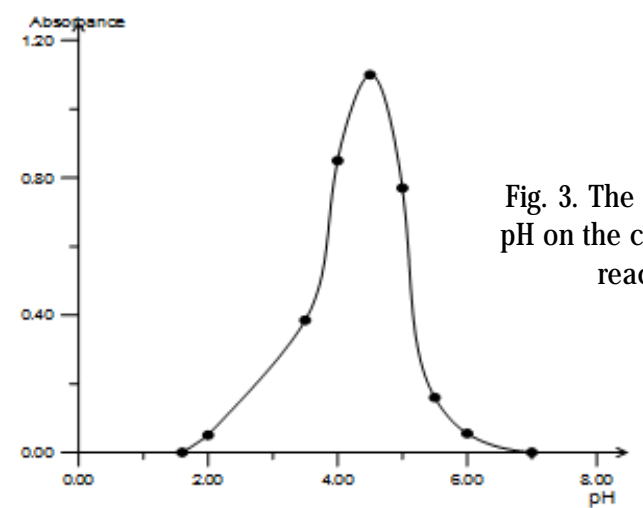

The complex formed within $10 \mathrm{~min}$ and it was stable for another 15 min (fig. 4).

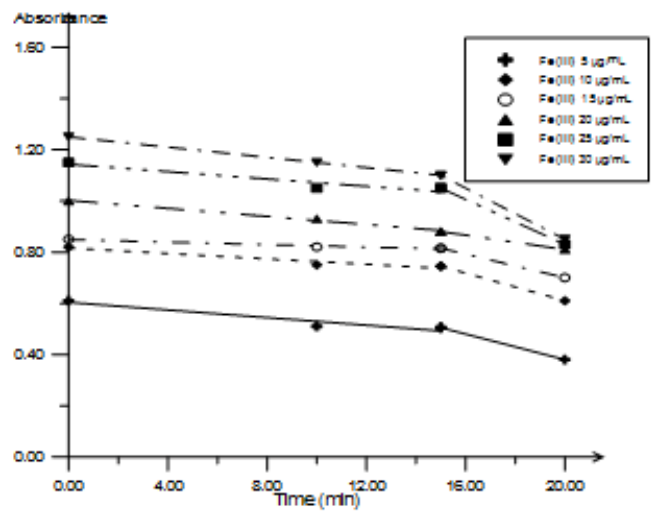

Fig. 4.

Complex stability in time

The combination rate was established using the isomolar series method (fig. 5).

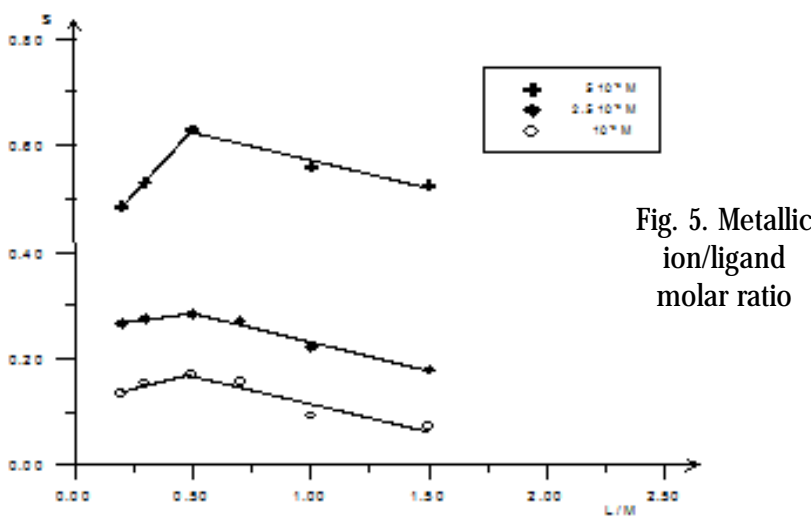

The value of the stability conditional constant (ân) was established using the formula: $\beta n=\left(\log C_{M} \cdot C_{C}\right) /(\log A-$ $n \cdot \log V$ ) [22], where: $C_{M}=$ molar concentration of the metallic ions ( $\mathrm{Fe}(\mathrm{III})$ ions), $\mathrm{C}_{\mathrm{L}}=$ molar concentration of the ligand $(B S B), A=$ absorbance of the metal-ligand complex measured at $520 \mathrm{~nm}, n=M / L$ molar ratio; $V=$ the volume of the solution $(5 \mathrm{~mL}) ; \varepsilon=$ molar extinction coefficient $=$ $5.99 \cdot 10^{4} \mathrm{~mol}^{-1} \cdot \mathrm{L}^{\circ} \mathrm{Cm}^{-1}$. According to the data collected, the obtained value of the stability conditional constant was $\beta \mathrm{n}$ $=5.74 \cdot 10^{-5}$.

For the study of the linearity of the method, four series of $\mathrm{Fe}(\mathrm{III})$ solutions in the $5-30 \mu \mathrm{g} / \mathrm{mL}$ concentration range had been used. The obtained data was statistically evaluated (table 1) and the calibration curve was obtained (fig. 6).

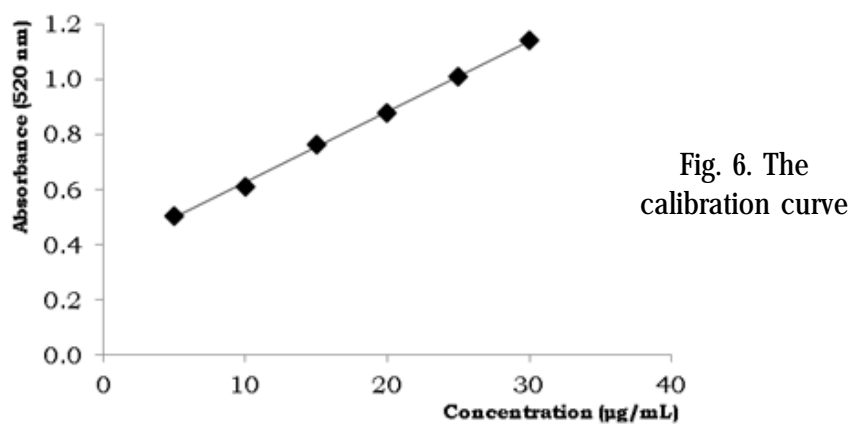

The detection limit (LOD) and the quantification limit (LOQ) were calculated: $\mathrm{LOD}=0.35 \mu \mathrm{g} / \mathrm{mL}$ and $\mathrm{LOQ}=$ $12.56 \mu \mathrm{g} / \mathrm{mL}$.

The precision of the system was assessed by performing 10 determinations of a $10 \mu \mathrm{g} / \mathrm{mL}$ sample, and the average value, the standard deviation and the relative standard deviation were calculated (table 2). The RSD was 1.32\%, so the Fe(III) determination method using the VIS spectrophotometric method was precise. The sample concentration was calculated using the calibration curve equation. The relative standard deviation was lower than $2 \%(\mathrm{RSD}=1.46 \%)$ for each set of data. All these values confirmed that the proposed method was precise (table 2).

For the accuracy study, the concentration of the sample was calculated from the experimental value of the absorbance, using the regression curve equation (table 3 ). We observed that the recovery was for the studied concentration range, the mean (minimum was $98.06 \%$ and maximum was $100.66 \%$ and the relative standard deviation was under $2 \%(\operatorname{RSD}=1.30 \%)$. These values proved that the $\mathrm{Fe}(\mathrm{III})$ determination method is accurate.

The method was used for the determination of Fe(III) in effervescent tablets from a commercially available pharmaceutical product with multivitamins and multiminerals (table 4).

\begin{tabular}{|c|c|c|c|c|c|c|}
\hline \multirow{2}{*}{$\mathrm{N}^{\circ}$} & \multirow{2}{*}{$\begin{array}{c}\text { Concentration } \\
(\mu \mathrm{g} / \mathrm{mL})\end{array}$} & \multicolumn{5}{|c|}{ Absorbance $(520 \mathrm{~nm})$} \\
\hline & & I & II & III & IV & Average \\
\hline 1. & 5 & 0.51532 & 0.51714 & 0.47974 & 0.50779 & 0.50499 \\
\hline 2. & 10 & 0.64515 & 0.63546 & 0.54848 & 0.61730 & 0.61160 \\
\hline 3. & 15 & 0.75579 & 0.76521 & 0.76276 & 0.76305 & 0.76170 \\
\hline 4. & 20 & 0.88098 & 0.88025 & 0.87866 & 0.86681 & 0.87668 \\
\hline 5. & 25 & 1.04576 & 1.03828 & 0.97101 & 0.97905 & 1.00853 \\
\hline 6. & 30 & 1.11095 & 1.15601 & 1.14776 & 1.15387 & 1.14215 \\
\hline \multicolumn{7}{|c|}{$\begin{array}{c}\text { Absorbance }=0.0257 \times \text { Concentration }+0.3685 \\
\text { Correlation and regression coefficients: } \mathrm{r}=0.9989, \mathrm{r}^{2}=0.9988 \\
\text { Standard error }=0.003028 \text {, Intercept }=0.368496 \pm 0.002068 \\
\text { Slope }=0.025671 \pm 0.000667\end{array}$} \\
\hline
\end{tabular}

Table 1

LINEARITY OF THE METHOD 


\begin{tabular}{|c|c|c|}
\hline No & Absorbance & Statistical Data \\
\hline 1 & 0.61235 & Mean $=0.6065$ \\
\hline 2 & 0.60856 & SD $=0.0080$ \\
\cline { 1 - 2 } RSD $=1.32 \%$ \\
\hline 4 & 0.61305 & \\
\hline 5 & 0.60895 & \\
\hline 6 & 0.60725 & \\
\hline 7 & 0.61678 & \\
\hline 8 & 0.59815 & \\
\hline 9 & 0.61165 & \\
\hline 10 & 0.59362 & \\
\hline & 0.59536 & \\
\hline
\end{tabular}

Table 2

PRECISION OF THE SYSTEM

\begin{tabular}{|c|c|c|c|c|c|c|}
\hline \multirow{2}{*}{$\begin{array}{l}\mathrm{Fe}(\mathrm{III}) \\
\mu \mathrm{g} / \mathrm{mL}\end{array}$} & \multicolumn{2}{|c|}{ Method precision } & \multicolumn{2}{|c|}{ Intermediate precision } & \multicolumn{2}{|c|}{ Accuracy } \\
\hline & Absorbance & Recovery $\%$ & Absorbance & Recovery \% & Absorbance & Recovery $\%$ \\
\hline \multirow{3}{*}{15} & 0.75697 & 100.77 & 0.75355 & 99.88 & 0.75657 & 100.67 \\
\hline & 0.74255 & 97.03 & 0.75459 & 100.15 & 0.74855 & 98.59 \\
\hline & 0.74696 & 98.17 & 0.74566 & 97.87 & 0.75096 & 99.04 \\
\hline \multirow{3}{*}{20} & 0.87668 & 98.87 & 0.87625 & 98.78 & 0.87658 & 98.85 \\
\hline & 0.88193 & 99.89 & 0.87855 & 99.23 & 0.88096 & 99.70 \\
\hline & 0.88941 & 101.34 & 0.88834 & 101.14 & 0.87341 & 98.23 \\
\hline \multirow{3}{*}{25} & 0.99752 & 97.90 & 0.99584 & 97.64 & 0.99852 & 98.06 \\
\hline & 1.00256 & 98.69 & 1.01895 & 101.24 & 1.01458 & 100.56 \\
\hline & 1.01348 & 100.39 & 1.00421 & 98.24 & 1.00825 & 99.57 \\
\hline $\begin{array}{l}\text { Statistical } \\
\text { data }\end{array}$ & \multicolumn{2}{|c|}{$\begin{array}{c}\text { Mean Recovery }=99.23 \% \\
\operatorname{RSD}=1.46 \%\end{array}$} & \multicolumn{2}{|c|}{$\begin{array}{c}\text { Mean } \text { Recovery }=99.43 \% \\
\operatorname{RSD}=1.30 \%\end{array}$} & \multicolumn{2}{|c|}{$\begin{array}{c}\text { Mean }=99.25 \% \\
\operatorname{Min}=98.06 \% \\
\operatorname{Max}=100.66 \%\end{array}$} \\
\hline
\end{tabular}

Table 3

THE METHOD PRECISION AND ACCURACY

\begin{tabular}{|c|c|c|c|c|}
\hline $\begin{array}{c}\text { Pharmaceutical } \\
\text { product }\end{array}$ & $\begin{array}{c}\text { Labelled } \\
\text { amount } \\
(\mu \mathrm{g} / \mathrm{tablet})\end{array}$ & $\begin{array}{c}\text { Assessed } \\
\text { amount } \\
(\boldsymbol{\mu} \mathrm{g} / \mathrm{tablet})\end{array}$ & $\begin{array}{c}\text { Recovery } \\
(\%)\end{array}$ & $\begin{array}{c}\text { RSD } \\
(\%)\end{array}$ \\
\hline $\begin{array}{c}\text { commercially } \\
\text { available effervescent } \\
\text { tablets }\end{array}$ & 125 & $123.98 \pm 1.175$ & 99.27 & 1.47 \\
\hline
\end{tabular}

Table 4

QUANTITATIVE DETERMINATION OF Fe (III) FROM EFFERVESCENT TABLETS

\section{Conclusions}

A new spectrophotometric method for the assay of $\mathrm{Fe}$ (III) was developed, based on Fe(III) complexation reaction with a bis-Schiff base. The complex had a maximum of absorption at $520 \mathrm{~nm}$. The analyzed method has been validated, establishing the optimum wavelength of detection, the linearity (in the range of the $5-30 \mu \mathrm{g} / \mathrm{mL}, \mathrm{r}$ $=0.9989$ ), the detection limit (LOD $=0.35 \mu \mathrm{g} / \mathrm{mL}$ ), the quantification limit ( $\mathrm{LOQ}=12.56 \mu \mathrm{g} / \mathrm{mL}$ ), the precision of the method (RSD $=1.46 \%$ ) and the accuracy (mean = $99.25 \%$, minimum $=98.06$, maximum $=100.66 \%$ ).

In conclusion, the proposed method is linear, precise, accurate, simple and fast, and it was used for the quantitative assay of Fe(III) from pharmaceutical product containing the analyzed ion.

\section{References}

1. GRECU, I., NEAMTU, M., ENESCU, I., Implicatii biologice si medicale ale chimiei anorganice. Editura Junimea, lasi, 1982.

2. SINGH, V., SINGH, S., NARANY, K., J. Enzyme Inhib. Med. Chem., 24 2009, p. 105

3. SINGH, D.P., KUMOR, K., SHARMA, C., Eur. J. Med. Chem., 44, no. 8, 2009, p. 3299.

4. ZAMFIR, G., STANICA, N., DRAGHICI, C., RUSU, E., KRIZA A., Rev Chim. (Bucharest), 63, no. 4, 2012, p. 416.

5. TANTARU, G., APOSTU M., Rev. Chim. (Bucharest), 61, no. 7, 2010, p. 632

6. CIOANCA, E. R., CARLESCU, I., WILSON, D., SCUTARU, D., Rev. Chim. (Bucharest), 61, no. 12, 2010, p. 1158.

7. LEDETI I.V., BERCEAN, V.N., TANASE, I.M., CREANGA A.A., BADEA, V., CSUNDERLIK, C., Rev. Chim. (Bucharest), 61, no. 10, 2010, p. $937-$ 939.

8. BERDAN, I., ANCUTA, D., SANDU, I., Revue Roumaine de Chimie, 30, no. 11-12, 1985, p. 1031.

9. CALU, N., SANDU, I., BANGOURA, M., CALU, M., Rev. Chim. (Bucharest), 42, no. 4-5, 1991, p. 226.

10. GULYA, A.P., NOVITSKII, G.V., TIMKO, G.A., SANDU, I., Koordinatsionnaya Khimiya, 20, no. 4, 1994, p. 290.
11. SANDU, I., GULEA, A., SANDU, I.C.A., LUCA, C., SANDU, I.G., Rev. Chim. (Bucharest), 56, no. 8, 2005, p. 805.

12. GULEA, A., NOVITCKI, G., SHOVA, S., SANDU, I., Revue Roumaine de Chimie, 38, no. 5, 1993, p. 505.

13. CALU, N., BALANESCU, E., BERDAN, I., SANDU, I., Revue Roumaine de Chimie, 31, no. 1, 1986, p. 71

14. GULYA, A.P., NOVITSKII, G.V., SHOVA, S.G., MAZUS, M.D., SANDU, I., Koordinatsionnaya Khimiya, 19, no. 3, 1993, p. 227.

15. BERDAN, I., SANDU, I., Revue Roumaine de Chimie, 33, no. 1, 1988, p. 67.

16. CASCAVAL, A., Brevet Romania nr. 89338, C.A. 106, 66901h, 1987.

17. ANDRONESCU, C., STANESCU, P. O., GAREA, S. A., IOVU M., Mat. Plast., 50, no. 2, 2013, p. 146.

18. TANTARU, G., MARIN, L., VIERIU, M., PANAINTE, A.D., POIATA, A., APOSTU M., BIBIRE, N., Rev. Chim. (Bucharest), 66, no. 12, 2015, p. 1965.

19. MIHAI, S., NEGOIU, M., BONDAREV, A., Rev. Chim. (Bucharest), 60, no. 8, 2009, p. 778.

20. GREEN, J.M., Anal .Chem. News \& Features, 305A/309A, 1996

21. ROMAN, L., BOJITA, M., SANDULESCU, R., Validarea metodelor de analiza si control. Editura Medicala, Bucuresti, 1998.

22. TANTARU, G., STAN, C.D., CRIVOI, F., Farmacia, 59, no. 2, 2011, p. 265.

23. OPREAN, R., ROZET. E., DEWE, W., BOULANGER, B., HUBERT, P., Ghid de validare a procedurilor analitice cantitative, Editura Medicala Universitara Iuliu Hateganu, Cluj-Napoca, 2007.

24.*** US EPA Guidance for methods development and methods validation for the Resource Conservation and Recovery Act (RCRA) Program, Washington, 1995.

25.*** International Conference on Harmonization (ICH) of Technical Requirements for the Registration of Pharmaceuticals for Human Use- Q2 (R1). Validation of analytical procedures: text and methodology, Geneva, 2005.

26. GHERMAN, S., ZAVASTIN, D., SPAC, A.F., DORNEANU, V., Rev. Chim. (Bucharest), 64, no. 11, 2013, p. 1224.

27. MANDRESCU, M., SPAC, A.F., DORNEANU, V., Rev. Chim. (Bucharest), 60, no. 2, 2009, p. 160. 